Check for updates

Cite this: Chem. Commun., 2021, 57, 3793

Received 17th February 2021, Accepted 11th March 2021

DOI: $10.1039 / \mathrm{d} 1 \mathrm{cc} 00898 \mathrm{f}$

rsc.li/chemcomm

\section{Hybrids of cationic [4] helicene and N-heterocyclic carbene as ligands for complexes exhibiting (chir)optical properties in the far red spectral window $\dagger$}

\author{
Robert Tarrieu, ${ }^{a}$ Irene Hernandez Delgado, ${ }^{b}$ Francesco Zinna, (D) ${ }^{\text {bc }}$ Vincent Dorcet, $^{d}$ \\ Sophie Colombel-Rouen, ${ }^{a}$ Christophe Crévisy, (D) *a Olivier Baslé, (D) *ae \\ Johann Bosson (iD ${ }^{* b}$ and Jérôme Lacour (iD *b
}

Synthesis, electronic and structural properties of a chiral NHC bearing a $\mathrm{N}$-bonded cationic [4] helicene moiety are reported. This ligand is used to construct $\mathrm{Au}^{\prime}, \mathrm{Au}^{\prime \prime \prime}$ and $\mathrm{Rh}^{\prime}$ complexes exhibiting far-red (chir)optical properties regardless of the metal.

In recent decades, N-heterocyclic carbenes (NHCs) have become ubiquitous ligands able, in the context of optical devices, to form robust organometallic complexes with luminescent properties. ${ }^{1-6}$ In most cases, the luminescence arises from the metal center and its coordination sphere, and it occurs predominantly at high energy (UV or blue-green spectral range). In the meantime, new NHC structures affording unique stereo-electronic properties have been prepared, ${ }^{7,8}$ and unsymmetrical unsaturated N-heterocyclic carbenes $\left(\mathrm{U}_{2}-\mathrm{NHCs}\right)$ in particular, ${ }^{9-13}$ allowing for instance the introduction of cycloalkyl or cationic cyclopropenium chains onto the diaminocarbene unit (e.g., A and B, Fig. 1). ${ }^{14}$ In addition, chiral NHCs are readily prepared, ${ }^{15-18}$ some of them using helicenes as stereogenic elements. ${ }^{19-24}$ Helicenes are orthocondensed polyaromatic molecules, inherently chiral due to the steric repulsion of their skeleton termini. ${ }^{25-31}$ Generally, they display absorption and emission properties in the UV and blue regions of light, ${ }^{32-34}$ with redshifted (chir)optical properties for some particular derivatives. ${ }^{35-39}$ In previous helicene-NHC based

\footnotetext{
${ }^{a}$ Univ Rennes, Ecole Nationale Supérieure de Chimie de Rennes,

CNRS, ISCR - UMR 6226, Rennes F-35000, France

E-mail: christophe.crevisy@ensc-rennes.fr

${ }^{b}$ Department of Organic Chemistry, University of Geneva, Quai Ernest Ansermet,

30, Geneva 4 CH-1211, Switzerland. E-mail: johann.bosson@unige.ch,

jerome.lacour@unige.ch

${ }^{c}$ Dipartimento di Chimica e Chimica Industriale, University of Pisa,

via G. Moruzzi 13, Pisa, Italy

${ }^{d}$ Univ Rennes, CNRS, ISCR - UMR 6226, Rennes F-35000, France

${ }^{e}$ LCC-CNRS, Université de Toulouse, CNRS, UPS, Toulouse, France.

E-mail: olivier.basle@lcc-toulouse.fr

$\dagger$ Electronic supplementary information (ESI) available: Experimental conditions, full characterizations of new compounds; UV-Vis, ECD, fluorescence and CPL spectra; computational details. CCDC 2061397 and 2061398. For ESI and crystallographic data in CIF or other electronic format see DOI: 10.1039/d1cc00898f
}

organometallic complexes, effective metal centered (chir)optical properties were engineered and happened at high energy. ${ }^{19,20,23,24}$ Herein, a different approach is detailed based on ligand-controlled luminescence. Synthetically, using a one-pot multicomponent procedure, ${ }^{13}$ cationic [4] helicene aniline $\mathbf{1}-\mathbf{N H}_{2}\left(\mathrm{BF}_{4}\right)^{38,40}$ and cyclododecylamine are combined to generate imidazolium $2 \cdot \mathrm{H}\left(\mathrm{PF}_{6}\right)_{2}$ (Fig. 1). The hybrid NHC ligand $2\left(\mathrm{PF}_{6}\right)$ is readily formed and affords stable $\mathrm{Rh}^{\mathrm{I}}, \mathrm{Au}^{\mathrm{I}}$ and $\mathrm{Au}{ }^{\mathrm{III}}$ complexes. The NHC steric and electronic properties are discussed. Low energy absorption and emission of the cationic [4] helicene moiety are maintained. Regardless of the organometallic species, intense (chir)optical properties are observed in the far-red spectral region, which can be beneficial for bio-related applications. ${ }^{41}$

For the preparation of targeted imidazolium salt $2 \cdot \mathrm{H}\left(\mathrm{PF}_{6}\right)_{2}$, unfunctionalized cationic diaza[4] helicene 1-H(BF $\left.\mathrm{BF}_{4}\right)$ (Fig. 1, $\mathrm{X}=\mathrm{H}),{ }^{40}$ was converted into aniline $\mathbf{1}-\mathbf{N H}_{2}\left(\mathrm{BF}_{4}\right)$ using a reported two-step sequence (nitration-reduction). ${ }^{38}$ Then, using conditions particularly efficient for the preparation of $\mathrm{U}_{2}$-NHCs precursors made of sterically hindered anilines, ${ }^{13} \mathbf{1}-\mathbf{N H}_{\mathbf{2}}\left(\mathrm{BF}_{4}\right)$ was engaged with equimolar amounts of cyclododecylamine,

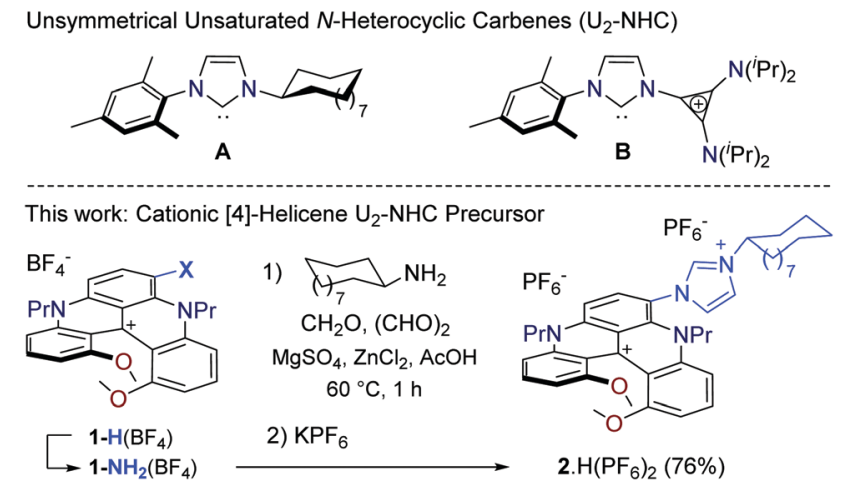

Fig. 1 Top: Examples of unsymmetrical unsaturated $\mathrm{N}$-heterocyclic carbenes $\left(\mathrm{U}_{2}-\mathrm{NHCs}\right)$. Bottom: Preparation of bis cationic imidazolium salt 2. $\mathrm{H}\left(\mathrm{PF}_{6}\right)_{2}$ from cationic [4] helicene aniline 1- $\mathrm{NH}_{\mathbf{2}}\left(\mathrm{BF}_{4}\right),(P)$-configuration shown arbitrarily. 
glyoxal and formaldehyde in the presence of zinc chloride and acetic acid. After counterion metathesis, the unsymmetrical bis cationic imidazolium salt $2 \cdot \mathrm{H}\left(\mathrm{PF}_{6}\right)_{2}$ was obtained with a high selectivity (93\%) over the bis cyclododecyl counterpart and was isolated as a dark blue-green solid in $76 \%$ yield (Fig. 1). As for NHC B (Fig. 1) ${ }^{14}$ the presence of the positive charge on the [4] helicene moiety was not a problem for the construction of organometallic complexes. After the in situ generation of free NHC $2\left(\mathrm{PF}_{6}\right)$ using potassium tert-butoxide as a base, standard metalation procedures afforded selenium adduct $3\left(\mathrm{PF}_{6}\right)$, rhodium $(\mathrm{I})$ $\mathbf{4}\left(\mathrm{PF}_{6}\right)$, gold( $\left.\mathrm{I}\right) \mathbf{5}\left(\mathrm{PF}_{6}\right)$ and gold(III) $\mathbf{6}\left(\mathrm{PF}_{6}\right)_{2}$ complexes in good yields (51-81\%, Fig. 2); all compounds display a dynamic atropisomerism that will be detailed in the following paragraphs. In practice, trapping of $2\left(\mathrm{PF}_{6}\right)$ with selenium (excess) led to selenourea $3\left(\mathrm{PF}_{6}\right)$ as a mixture of two inseparable stereoisomers $\left(75 \%, 3: 2\right.$ ratio, ${ }^{1} \mathrm{H}$ and ${ }^{77}$ Se NMR, Fig. S26 and S30, ESI $\left.\dagger\right)$. Reaction of $2\left(\mathrm{PF}_{6}\right)$ with $[\mathrm{Rh}(\mathrm{cod}) \mathrm{Cl}]_{2}$ dimer yielded (NHC)RhCl(cod) complex $\mathbf{4}\left(\mathrm{PF}_{6}\right)(69 \%$ yield; atropisomeric ratio a.r. $3: 2$ ). The preparation of gold complexes $\mathbf{5}\left(\mathrm{PF}_{6}\right)$ and $\mathbf{6}\left(\mathrm{PF}_{6}\right)_{2}$ was achieved by reactions with $\mathrm{AuCl} \cdot \mathrm{SMe}_{2}$ and bis-cyclometalated 2,6-diphenylpyridyl gold(III) complex, respectively. $\mathbf{5}\left(\mathrm{PF}_{6}\right)$ was isolated in $51 \%$ yield (a.r. $\left.3: 2\right)$, whereas $\mathbf{6}\left(\mathrm{PF}_{6}\right)_{2}$ was formed in $81 \%$ yield, only one apparent stereoisomer being observed in this case at $298 \mathrm{~K}$ (vide infra).

As above-noted, compounds 3 to 5 displayed in NMR spectroscopy two sets of signals on the NMR time scale. This behavior results from the restricted rotation around the $\mathrm{C}-\mathrm{N}$ bond ${ }^{42}$ linking the helicene and the imidazole moieties. In fact, the steric hindrance about the $\mathrm{C}-\mathrm{N}$ bond generates pairs of atropisomers, for instance of $(\mathrm{a} S, P)$ and $(\mathrm{a} R, P)$ configurations (Fig. 3); the atropisomeric ratio depending upon the encumbrance of the substituted carbene fragment. To explain the situation, care must be taken to consider NMR solution and $\mathrm{X}$-ray crystallographic studies that have previously indicated that substituents at position of 6 of the helicene induce a strong conformational constraint onto the neighboring $N$-alkyl chains. ${ }^{38}$ The impacted propyl residues display gauche conformations
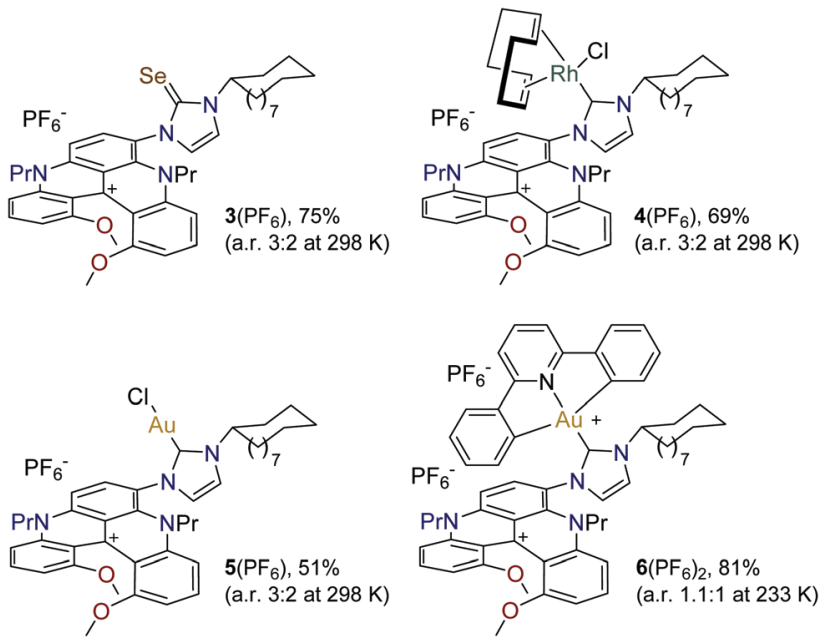

Fig. 2 Selenium adduct $3\left(\mathrm{PF}_{6}\right)$, rhodium $(\mathrm{I}) \mathbf{4}\left(\mathrm{PF}_{6}\right)$, gold $(\mathrm{I})$ and gold(III) complexes $5\left(\mathrm{PF}_{6}\right)$ and $\mathbf{6}\left(\mathrm{PF}_{6}\right)_{2}$ prepared from $\mathbf{2} \cdot \mathrm{H}\left(\mathrm{PF}_{6}\right)_{2}$. $(P)$ enantiomers shown. a.r.: atropisomeric ratio.



Fig. 3 Atropisomers $(a S, P)$ and $(a R, P)$ formed with helicenes of $(P)$ configuration.

(instead of classical anti conformations) and, consequently, they fold above the helical core (Fig. 3, blue propyl chain). This is particularly well observed in ${ }^{1} \mathrm{H}$ NMR spectroscopy with the terminal methyl groups being shifted at lower frequency by $-0.8 \mathrm{ppm}$. As a consequence, strong steric interactions occur between the curved propyl chain and metal coordination spheres at immediate proximity favoring the less hindered conformations that orientate the propyl chain and metal centers in opposite directions. Considering a $(P)$ configuration for the helicene, the (aS,P) conformation is then favored over the diastereomeric ( $\mathrm{a} R, P)$ geometry (Fig. 3, right vs. left).

The atropisomeric situation was investigated in silico. Conformational search (B3LYP/6-311G**) for a simplified version of selenium adduct $(P)-3$ was performed (see ESI $\dagger$ ). The two conformers depicted in Fig. 3 were found to be the most stable structures, the $a S$ isomer being more stable by $0.2 \mathrm{kcal} \mathrm{mol}^{-1}$, which corresponds to an equilibrium ratio of $0.58: 0.42$ at $25{ }^{\circ} \mathrm{C}$. This is in good agreement with the experimental 0.6:0.4 value (vide supra). Moreover, the transition state of the $a S \rightarrow a R$ isomerization was located at $+17.2 \mathrm{kcal} \mathrm{mol}^{-1}$ which is consistent with a facile epimerization at room temperature and yet with the possibility to distinguish the two species on the NMR time scale. ${ }^{43}$ Similarly, for $\mathbf{4}$ and $\mathbf{5}$, the calculated ratios were found to be in good agreement with ${ }^{1}$ H NMR spectroscopy (Table S1, ESI $\dagger$ ). For compound 6, to our initial surprise, the computed energy difference between the stereoisomers was only of $0.1 \mathrm{kcal} \mathrm{mol}^{-1}$ (a.r. $0.54: 0.46$ at $298 \mathrm{~K}$ ). Such a ratio could only be confirmed experimentally at lower temperature (a.r. $0.52: 0.48$ at $233 \mathrm{~K}$, see Fig. S43, ESI $\dagger$ ). ${ }^{44}$ Solid state structures of $3\left(\mathrm{PF}_{6}\right)$ and complex $4\left(\mathrm{PF}_{6}\right)$ were further obtained by X-ray diffraction analysis (Fig. 2, see also ESI, $\dagger$ for topographic steric maps and associated \%Vbur values).$^{45}$ In both cases, a single atropisomer was found in the crystal packing with a configuration opposite to that predicted computationally. It is most probably the result of intermolecular packing interactions and it also confirms the facile epimerization.

NHC ligands are reputed to stabilize organometallic complexes via the formation of strong metal carbene bonds that are related to the $\sigma$-donor character of the carbenic position and its ability to accept $\pi$-back-bonding from the metal center. Considering the unusual cationic character of $\mathrm{NHC} 2\left(\mathrm{PF}_{6}\right)$, the electronic properties of such species were investigated and are compiled in Table 1. First, the $\sigma$-donor ability of the NHC was assessed by measuring the ${ }^{1} J_{\mathrm{CH}}$ coupling constant between the carbon and hydrogen atom at the pre-carbenic position of precursor $2 \cdot \mathrm{H}\left(\mathrm{PF}_{6}\right)_{2} \cdot{ }^{46,47}$ The value of ${ }^{1} J_{\mathrm{CH}}=224 \mathrm{~Hz}$ measured 
Table 1 Electronic parameters of selected imidazol-2-ylidenes

\begin{tabular}{llll}
\hline $\mathrm{NHC}$ & ${ }^{1} J_{\mathrm{C}-\mathrm{H}}{ }^{a}(\mathrm{~Hz})$ & $\delta\left({ }^{77} \mathrm{Se}\right)^{b}(\mathrm{ppm})$ & $\mathrm{TEP}\left(\mathrm{cm}^{-1}\right)$ \\
\hline $\mathbf{A}$ & 222 & 10 & 2050.5 \\
B & 229 & 112 & 2057 \\
2 & 224 & 65,49 & 2055.1
\end{tabular}

${ }^{a}$ Measured on the NHC $\mathrm{H}$ precursors. ${ }^{b}$ Measured on the NHC-Se adducts.

for $2 \cdot \mathrm{H}\left(\mathrm{PF}_{6}\right)_{2}$ was found slightly superior to that of $\mathbf{A}\left({ }^{1} J_{\mathrm{CH}}=222 \mathrm{~Hz}\right)$ bearing the neutral mesityl fragment, and inferior to the $229 \mathrm{~Hz}$ reported for the cyclopropylium moiety $\mathbf{B},{ }^{14}$ highlighting the somewhat low withdrawing character of cationic [4] helicene substituent. The $\pi$-character of NHCs can be tabulated using ${ }^{77}$ Se NMR spectroscopy. ${ }^{48,49}$ The two isomers of the NHC-Se adduct $3\left(\mathrm{PF}_{6}\right)$ exhibited ${ }^{77} \mathrm{Se}$ resonances at 65 and $49 \mathrm{ppm}$, downfield shifted compared to A-Se adduct $\left(\delta_{\mathrm{Se}}=10 \mathrm{ppm}\right)$ revealing a slight increase of the $\pi$-character as compared to this neutral species, but less pronounced than for cationic B-Se adduct (122 ppm). ${ }^{14}$ Finally, the Tolman Electronic Parameters (TEP) value of $\mathrm{NHC} 2\left(\mathrm{PF}_{6}\right)$ was also investigated. The TEP allows to describe the effects of the combination of the $\sigma$-donor and $\pi$-acceptor characters modulated by the sterics of the ligand. ${ }^{50}$ For that purpose, the (NHC)RhCl(cod)complex $4\left(\mathrm{PF}_{6}\right)$ was converted under a carbon monoxide atmosphere to the corresponding $(\mathrm{NHC}) \mathrm{RhCl}(\mathrm{CO})_{2}$ complex and allowed in situ measurement of the average IR stretching of the carbonyl ligands (Fig. S19, ESI $\dagger$ ). The calculated TEP value of $2055.1 \mathrm{~cm}^{-1}$ between neutral unsaturated NHCs (i.e. TEP $2050.5 \mathrm{~cm}^{-1}$ for A) and cationic NHC B $\left(2057 \mathrm{~cm}^{-1}\right)$ is consistent with measured ${ }^{1} J_{\mathrm{CH}}$ and ${ }^{77}$ Se values indicating that the positive charge has a significant effect on the electronic properties of 2, lowering thus the $\sigma$-donation and increasing the $\pi$-acceptation, effect however less pronounced than that observed in the cationic $\mathbf{B}$.

The optical properties of compounds $2 \cdot \mathrm{H}\left(\mathrm{PF}_{6}\right)_{2}$ to $6\left(\mathrm{PF}_{6}\right)_{2}$ were recorded in acetonitrile solutions and compared to that of parent cationic[4] helicene $\mathbf{1}-\mathbf{H}\left(\mathrm{BF}_{4}\right)$ (Fig. 4, top and Table 2). The functionalization of 1-H ( $\left.\lambda_{\mathrm{abs}}: 616 \mathrm{~nm}, \lambda_{\mathrm{em}}: 667 \mathrm{~nm}\right)$ with electron-withdrawing groups (EWG) at position 6 is documented to induce rather strong hypsochromic shifts in absorption and emission. ${ }^{38} 2 \cdot \mathrm{H}\left(\mathrm{PF}_{6}\right)_{2}$ exhibits a moderately intense absorption band in the orange-red region ( $\lambda_{\mathrm{abs}}: 599 \mathrm{~nm}, \varepsilon: 11500 \mathrm{M} \mathrm{cm}^{-1}$ ) and fluoresces in the far red ( $\phi_{\text {flu }}: 0.26$ at $\left.644 \mathrm{~nm}\right)$. The slight blue shifts observed as compared to 1-H indicate that the imidazolium cationic part can be described as a mild EWG, comparable in intensity to a ketone moiety. ${ }^{38}$ The lowest energy transition of the selenium adduct $3\left(\mathrm{PF}_{6}\right)$ is centered on $613 \mathrm{~nm}\left(\varepsilon=9300 \mathrm{M} \mathrm{cm}^{-1}\right)$ but this compound is essentially non-emissive. ${ }^{51}$ As expected, the characteristic optical properties of the diaza[4] helicene 1-H are maintained in the organometallic complexes 4-6 with only a marginal influence of the metallic centers (Table 2). The lowest energy transitions are centered between $600\left(6\left(\mathrm{PF}_{6}\right)_{2}\right)$ and 609 $\left(4\left(\mathrm{PF}_{6}\right)\right) \mathrm{nm}$ with $\varepsilon$ values spanning from 9800 to $13200 \mathrm{M}^{-1} \mathrm{~cm}^{-1}$. Similarly, no significant changes are observed in emission, all derivatives being efficient fluorophores in the far red ( $\phi_{\text {flu }}: 0.14-0.23$, $\left.\lambda_{\text {em }} 644-653 \mathrm{~nm}\right)$.

$\mathrm{Au}^{\mathrm{III}}$ complex $6\left(\mathrm{PF}_{6}\right)_{2}$ was selected to investigate the chiroptical properties of this family of compounds (Fig. 4, bottom).
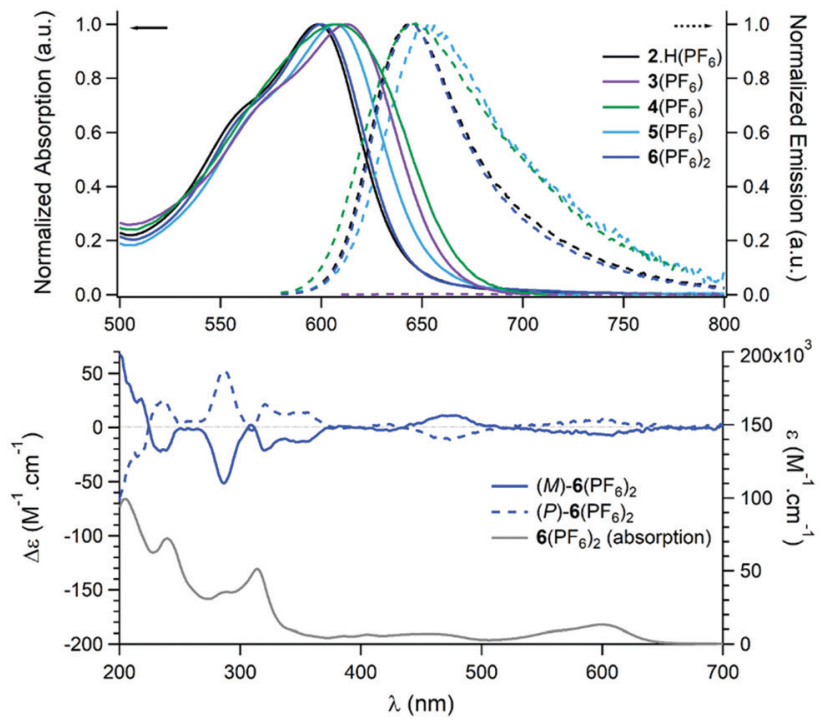

Fig. 4 Top: Normalized absorption (plain lines) and emission (dashed lines) spectra of $\mathbf{2} \cdot \mathrm{H}\left(\mathrm{PF}_{6}\right)-\mathbf{6}\left(\mathrm{PF}_{6}\right)_{2}$ recorded in acetonitrile $\left(\mathrm{C} \mathrm{ca} \cdot 10^{-5} \mathrm{M}\right)$. Bottom: ECD spectra of $(M)-6\left(\mathrm{PF}_{6}\right)_{2}$ and $(P)-6\left(\mathrm{PF}_{6}\right)_{2}$ (blue lines) and absorption spectrum of $\mathbf{6}\left(\mathrm{PF}_{6}\right)_{2}$ (grey line), acetonitrile, $\left(\mathrm{C} \mathrm{ca.} 10^{-5} \mathrm{M}\right)$.

Table 2 Optical properties of $\mathbf{1}-\mathrm{H}\left(\mathrm{BF}_{4}\right), \mathbf{2} \cdot \mathrm{H}\left(\mathrm{PF}_{6}\right)_{2}$, adduct $\mathbf{3}\left(\mathrm{PF}_{6}\right)$ and complexes $4\left(\mathrm{PF}_{6}\right)-\mathbf{6}\left(\mathrm{PF}_{6}\right)_{2}$ recorded in acetonitrile solutions

\begin{tabular}{llcll}
\hline & $\lambda_{\mathrm{abs}}(\mathrm{nm})$ & $\varepsilon\left(\mathrm{M} \mathrm{cm}^{-1}\right)$ & $\lambda_{\mathrm{em}}(\mathrm{nm})$ & $\phi_{\mathrm{flu}}{ }^{a}$ \\
\hline $\mathbf{1}-\mathrm{H}_{(}\left(\mathrm{BF}_{4}\right)$ & 616 & 14000 & 667 & 0.13 \\
$\left.\mathbf{2} \cdot \mathrm{H} \mathrm{PF}_{6}\right)_{2}$ & 599 & 11500 & 644 & 0.26 \\
$\mathbf{3}\left(\mathrm{PF}_{6}\right)$ & 613 & 9300 & - & - \\
$4\left(\mathrm{PF}_{6}\right)$ & 609 & 13000 & 646 & 0.14 \\
$\mathbf{5}\left(\mathrm{PF}_{6}\right)$ & 607 & 9800 & 653 & 0.15 \\
$\mathbf{6}\left(\mathrm{PF}_{6}\right)_{2}$ & 600 & 13200 & 644 & 0.23 \\
${ }^{a}$ Quantum yields versus cresyl violet $\left(\phi_{\mathrm{flu}} 0.54\right.$ in $\left.\mathrm{MeOH}\right)$. &
\end{tabular}

The two enriched $(M)$ and $(P)$ enantiomers of $6\left(\mathrm{PF}_{6}\right)_{2}$ were prepared from the corresponding $(M)$ - and $(P)-\mathbf{1 - H}$. As usual for cationic helicenes, ${ }^{37,38,52,53}$ the two enantiomers of $6\left(\mathrm{PF}_{6}\right)_{2}$ exhibit strong specific rotations, $[\alpha]_{365}^{20}=-4000$ and +4300 for the $(M)$ and $(P)$ enantiomers, respectively. In Electronic Circular Dichroism (ECD) and in the visible range, $6\left(\mathrm{PF}_{6}\right)_{2}$ exhibits two rather strong Cotton effects centered at $600 \mathrm{~nm}\left(|\Delta \varepsilon|=8 \mathrm{M}^{-1} \mathrm{~cm}^{-1}\right)$ and at $479 \mathrm{~nm}\left(|\Delta \varepsilon|=11 \mathrm{M}^{-1} \mathrm{~cm}^{-1}\right)$. In the UV region, Cotton effects typical of helicene skeletons are observed at 237, 287 and $320 \mathrm{~nm}\left(|\Delta \varepsilon|=23,52\right.$ and $21 \mathrm{M}^{-1} \mathrm{~cm}^{-1}$, respectively). The Circularly Polarized Luminescence (CPL) of $6\left(\mathrm{PF}_{6}\right)_{2}$ was also measured in acetonitrile solution (Fig. S9, ESI $\dagger$ ). This species displays a

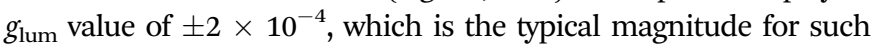
[4] helicenes. The CPL signal is centered on the maximum emission wavelength, which is strongly red-shifted as compared to most carbohelicenes. $^{54}$

In summary, a dicationic helicene-imidazolium hybrid was prepared following a high yielding multicomponent synthetic procedure, revealing a ligand characterized by an overall richness comparable to common neutral unsaturated NHCs and a certain structural flexibility. This helicene-NHC was used for 
the construction of $\mathrm{Rh}^{\mathrm{I}}, \mathrm{Au}^{\mathrm{I}}$ and $\mathrm{Au}^{\mathrm{III}}$ complexes that exhibit ligand controlled chiroptical properties in the far-red window.

This work was supported by the CNRS, the Ecole Nationale Supérieure de Chimie de Rennes, the Région Bretagne and Demeta (ARED No. COH14007 "NHC-MET" grant to R.T.), the University of Geneva and the Swiss National Science Foundation (grants 172497 and 184843).

\section{Conflicts of interest}

There are no conflicts to declare.

\section{Notes and references}

1 R. Visbal and M. C. Gimeno, Chem. Soc. Rev., 2014, 43, 3551-3574.

2 T. Zou, F. F. Hung, C. Yang and C. M. Che, Luminescent and Photoactive Transition Metal Complexes as Biomolecular Probes and Cellular Reagents, 2015, vol. 165, pp. 181-203.

3 C. Hemmert and H. Gornitzka, Dalton Trans., 2016, 45, 440-447.

4 C. Hille and F. E. Kuhn, Dalton Trans., 2016, 45, 15-31.

5 P. V. Simpson, M. Falasca and M. Massi, Chem. Commun., 2018, 54, 12429-12438.

6 I. Omae, Coord. Chem. Rev., 2016, 310, 154-169.

7 H. V. Huynh, Chem. Rev., 2018, 118, 9457-9492.

8 A. Gómez-Suárez, D. J. Nelson and S. P. Nolan, Chem. Commun., 2017, 53, 2650-2660.

9 A. Fürstner, M. Alcarazo, V. César and C. W. Lehmann, Chem. Commun., 2006, 2176-2178.

10 P. Queval, C. Jahier, M. Rouen, I. Artur, J.-C. Legeay, L. Falivene, L. Toupet, C. Crévisy, L. Cavallo, O. Baslé and M. Mauduit, Angew. Chem., Int. Ed., 2013, 52, 14103-14107.

11 S. Li, F. Yang, T. Lv, J. Lan, G. Gao and J. You, Chem. Commun., 2014, 50, 3941-3943.

12 C. Jahier-Diallo, M. S. T. Morin, P. Queval, M. Rouen, I. Artur, P. Querard, L. Toupet, C. Crévisy, O. Baslé and M. Mauduit, Chem. - Eur. J., 2015, 21, 993-997.

13 R. Tarrieu, A. Dumas, J. Thongpaen, T. Vives, T. Roisnel, V. Dorcet, C. Crévisy, O. Baslé and M. Mauduit, J. Org. Chem., 2017, 82, 1880-1887.

14 C. Barthes, C. Duhayon, Y. Canac and V. César, Chem. Commun., 2020, 56, 3305-3308.

15 F. Wang, L.-j. Liu, W. Wang, S. Li and M. Shi, Coord. Chem. Rev., 2012, 256, 804-853.

16 D. Janssen-Müller, C. Schlepphorst and F. Glorius, Chem. Soc. Rev., 2017, 46, 4845-4854.

17 P. J. Czerwiński and M. Michalak, Synthesis, 2019, 1689-1714.

18 J. Thongpaen, R. Manguin and O. Baslé, Angew. Chem., Int. Ed., 2020, 59, 10242-10251.

19 N. Hellou, C. Jahier-Diallo, O. Baslé, M. Srebro-Hooper, L. Toupet, T. Roisnel, E. Caytan, C. Roussel, N. Vanthuyne, J. Autschbach, M. Mauduit and J. Crassous, Chem. Commun., 2016, 52, 9243-9246.

20 N. Hellou, M. Srebro-Hooper, L. Favereau, F. Zinna, E. Caytan, L. Toupet, V. Dorcet, M. Jean, N. Vanthuyne, J. A. G. Williams, L. Di Bari, J. Autschbach and J. Crassous, Angew. Chem., Int. Ed., 2017, 56, 8236-8239.

21 I. G. Sanchez, M. Samal, J. Nejedly, M. Karras, J. Klivar, J. Rybacek, M. Budesinsky, L. Bednarova, B. Seidlerova, I. G. Stara and I. Stary, Chem. Commun., 2017, 53, 4370-4373.

22 M. Karras, M. Dabrowski, R. Pohl, J. Rybacek, J. Vacek, L. Bednarova, K. Grela, I. Stary, I. G. Stara and B. Schmidt, Chem. - Eur. J., 2018, 24, 10994-10998.

23 N. Hafedh, L. Favereau, E. Caytan, T. Roisnel, M. Jean, N. Vanthuyne, F. Aloui and J. Crassous, Chirality, 2019, 31, 1005-1013.

24 E. S. Gauthier, L. Abella, N. Hellou, B. Darquie, E. Caytan, T. Roisnel, N. Vanthuyne, L. Favereau, M. Srebro-Hooper, J. A. G. Williams,
J. Autschbach and J. Crassous, Angew. Chem., Int. Ed., 2020, 59, 8394-8400.

25 Y. Shen and C. F. Chen, Chem. Rev., 2012, 112, 1463-1535.

26 M. Gingras, Chem. Soc. Rev., 2013, 42, 1051-1095.

27 P. Aillard, A. Voituriez and A. Marinetti, Dalton Trans., 2014, 43, 15263-15278.

28 N. Saleh, C. S. Shen and J. Crassous, Chem. Sci., 2014, 5, 3680-3694.

29 J. Bosson, J. Gouin and J. Lacour, Chem. Soc. Rev., 2014, 43, $2824-2840$.

30 J. OuYang and J. Crassous, Coord. Chem. Rev., 2018, 376, 533-547. 31 I. G. Stara and I. Stary, Acc. Chem. Res., 2020, 53, 144-158.

32 E. M. Sanchez-Carnerero, A. R. Agarrabeitia, F. Moreno, B. L. Maroto, G. Muller, M. J. Ortiz and S. de la Moya, Chem. - Eur. J., 2015, 21, 13488-13500.

33 H. Isla and J. Crassous, C. R. Chim., 2016, 19, 39-49.

34 W. L. Zhao, M. Li, H. Y. Lu and C. F. Chen, Chem. Commun., 2019, 55, 13793-13803.

35 M. Li, Y. Niu, X. Zhu, Q. Peng, H. Y. Lu, A. Xia and C. F. Chen, Chem. Commun., 2014, 50, 2993-2995.

36 M. Li, W. Yao, J. D. Chen, H. Y. Lu, Y. S. Zhao and C. F. Chen, J. Mater. Chem. C, 2014, 2, 8373-8380.

37 J. Bosson, G. M. Labrador, S. Pascal, F. A. Miannay, O. Yushchenko, H. Li, L. Bouffier, N. Sojic, R. C. Tovar, G. Muller, D. Jacquemin, A. D. Laurent, B. Le Guennic, E. Vauthey and J. Lacour, Chem. - Eur. J., 2016, 22, 18394-18403.

38 I. H. Delgado, S. Pascal, A. Wallabregue, R. Duwald, C. Besnard, L. Guenee, C. Nancoz, E. Vauthey, R. C. Tovar, J. L. Lunkley, G. Muller and J. Lacour, Chem. Sci., 2016, 7, 4685-4693.

39 M. Li, H. Y. Lu, C. Zhang, L. Shi, Z. Tang and C. F. Chen, Chem. Commun., 2016, 52, 9921-9924.

40 C. Herse, D. Bas, F. C. Krebs, T. Burgi, J. Weber, T. Wesolowski, B. W. Laursen and J. Lacour, Angew. Chem., Int. Ed., 2003, 42, 3162-3166.

41 S. Wang, B. Li and F. Zhang, ACS Cent. Sci., 2020, 6, 1302-1316.

42 L. Kong, J. Morvan, D. Pichon, M. Jean, M. Albalat, T. Vives, S. Colombel-Rouen, M. Giorgi, V. Dorcet, T. Roisnel, C. Crévisy, D. Nuel, P. Nava, S. Humbel, N. Vanthuyne, M. Mauduit and H. Clavier, J. Am. Chem. Soc., 2020, 142, 93-98.

43 Considering first-order kinetics, kinetic constant of $1.50 \mathrm{~s}^{-1}$ and a half-life $t_{1 / 2}$ of $0.46 \mathrm{~s}$ at $298 \mathrm{~K}$ are calculated.

44 In addition, the activation energy is quite lower $\left(+13.5 \mathrm{kcal} \mathrm{mol}^{-1}\right)$ due possibly to steric buttressing.

45 L. Falivene, Z. Cao, A. Petta, L. Serra, A. Poater, R. Oliva, V. Scarano and L. Cavallo, Nat. Chem., 2019, 11, 872-879.

46 G. Meng, L. Kakalis, S. P. Nolan and M. Szostak, Tetrahedron Lett., $2019,60,378-381$.

47 K. Verlinden, H. Buhl, W. Frank and C. Ganter, Eur. J. Inorg. Chem., 2015, 2416-2425.

48 S. V. C. Vummaleti, D. J. Nelson, A. Poater, A. Gomez-Suarez, D. B. Cordes, A. M. Z. Slawin, S. P. Nolan and L. Cavallo, Chem. Sci., 2015, 6, 1895-1904.

49 A. Liske, K. Verlinden, H. Buhl, K. Schaper and C. Ganter, Organometallics, 2013, 32, 5269-5272.

50 D. J. Nelson and S. P. Nolan, Chem. Soc. Rev., 2013, 42, 6723-6753. 51 (a) Heavy atom effect ie, G. C. Hoover and D. S. Seferos, Chem. Sci., 2019, 10, 9182-9188; $(b)$ or photoinduced electron transfer ie. M. Rosenberg, A. K. R. Junker, T. J. Sørensen and B. W. Laursen, ChemPhotoChem, 2019, 3, 233-242; (c) K. Koren, N. K. G. Salinas, M. Santella, M. Mosshammer, M.-C. Mueller, R. I. Dmitriev, S. M. Borisov, M. Kühl and B. W. Laursen, Dyes Pigm., 2020, 173, 107866can be invoked for the non-emissive character.

52 S. Pascal, C. Besnard, F. Zinna, L. Di Bari, B. Le Guennic, D. Jacquemin and J. Lacour, Org. Biomol. Chem., 2016, 14, 4590-4594.

53 G. M. Labrador, J. Bosson, Z. S. Breitbach, Y. Lim, E. R. Francotte, R. Sabia, C. Villani, D. W. Armstrong and J. Lacour, Chirality, 2016, 28, 282-289.

54 C.-F. Chen and Y. Shen, Helicene Chemistry, Springer, Berlin, Heidelberg, 2017. 